\title{
SISI LAIN DARI MAKNA ASET EKONOMI
}

\author{
Irman Mamulati \\ Universitas Muhammadiyah Maluku Utara \\ irmanmamulati@gmail.com
}

\begin{abstract}
This study aims to reveal the other side of the meaning economic assets in Amal Usaha Muhammadiyah. This research uses qualitative paradigm with phenomenology interpretive methods to interpret the other side of the meaning economic assets in Amal Usaha Muhammadiyah as a research site. The result exposes other side of the meaning economic assets: first, the assets as a means of dakwah. Second, assets as a means of correlate fraternity. Third, the assets as a means of organizational sustainablility.
\end{abstract}

Kata Kunci: Aset Ekonomi, Sarana Dakwah, Bersilarurahmi, Keberlanjutan Organisasi, Amal Usaha Muhammadiyah, Fenomenologi

\section{PENDAHULUAN}

Sampai saat ini fenomena aset yang di pahami oleh para sebagian besar akademisi maupun para praktisi akuntansi berkaitan dengan pengakuan aset, yaitu harus terjadi transaksi di masa lalu, dapat dikuasai dan memberikan manfaat di masa yang akan datang. Hal tersebut dikarenakan selama ini pemahaman tersebut merujuk pada definisi aset yang di gagas Financial Accounting Standar Board (FASB) sebagaimana diterjemahkan Suwarjono (2006:252), yaitu:

"sebagai manfaat ekonomi masa mendatang yang cukup pasti yang diperoleh atau dikuasai/dikendalikan oleh suatu entitas sebagai akibat transaksi atau kejadian di masa lalu".

Definisi tersebut di setir oleh Ikatan Akuntansi Indonesia (IAI 2009) bahwa aset merupakan sumber daya yang dikuasai oleh perusahaan sebagai akibat transaksi di masa lalu dan memberikan manfaat di masa yang akan datang. Hal tersebut sesuai dengan definisi aset yang digagas oleh International Accounting Standards Committe (IASC 1997), yaitu:

"An asset is resource controlled by the enterprise as a result of past events and from which future economic benefits are expected to flow to the enterprise.

Makna aset yang dikemukakan oleh FASB, IAI dan IASC menyebabkan aset hanya diakui ketika memiliki tiga komponen tersebut, yaitu: memberikan manfaat di masa mendatang, dikuasai entitas dan terjadi transaksi. Jika ketiga komponen tersebut salah satunya tidak terpenuhi, maka tidak dapat diakui sebagai aset, karena aset yang dipahami hanyalah yang dapat memberikan manfaat ekonomi dan bukan merupakan sumber ekonomi. Suwarjono (2006:253) menjelaskan bahwa sumber ekonomik ini biasanya berupa potensi jasa atau kapasitas produksi yang berwujud (misanya tanah, gedung, mesin dan sediaan barang) dan kekayaan finansial (misalnya kas, piutang dan surat berharga). Jumlah rupiah melekat pada aset yang dianggap sebagai nilai ekonomi aset tersebut. Oleh sebab itu, Suwarjono

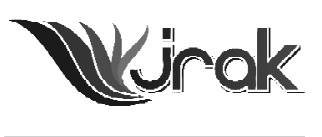

Jurnal Reviu Akuntansi dan Keuangan ISSN: 2088-0685 Vol.5 No. 2, Oktober 2015 Pp 741-750 
Sisi Lain

dari

Makna...

742
(2003:70) mendefinisikan aset sebagai kekayaan atau sumber ekonomi yang dikuasai perusahaan dan digunakan oleh perusahaan untuk mencapai tujuannya.

Tujuan yang akan ingin dicapai oleh suatu organisasi dalam pengelolaan aset tentunya berbeda. Jika organisasi bisnis dengan tujuan mendapat profit, maka aset yang dikelola juga harus menghasilkan laba. Lain halnya dengan organisasi non bisnis dengan tujuan non profit, maka aset yang dikelola untuk melayani masyarakat. Perbedaan ini dimungkinkan terjadi karena value basic yang mendasari interaksi bisnis maupun non bisnis di masing-masing organisasinya. Dengan demikian akan memberikan perspektif yang berbeda dalam memandang aset.

Penelitian tentang makna, simbol atau tanda aset masih sangat minim ditemukan, baik dalam organisasi profit oriented, maupun non profit oriented. Salah satu penelitian tentang makna aset melalui pendekatan natural telah dilakukan Wulandari (2012) di organisasi yang berorentasi profit oriented, yaitu PT. Arema Indonesia. Hasil penelitiannya mengungkap bahwa pemain sepak bola sebagai aset bergerak komersial, aset non-keuangan, dan aset sosio-ekonomis. Sementara penelitian tentang makna aset di lingkungan organisasi yang berorentasi non profit oriented dilakukan Widati (2011) pada organisasi Aisyiyah Kota Malang dan Luayyi (2012) di Pondok Pesanteren. Hasil penelitian Widati (2011) tentang aset dimaknai sebagai sarana beribadah, penggerak melakukan perintah Tuhan, dan segala upaya meraih derajat muhsinin. Selain itu, hasil penelitian Luayyi (2012) menunjukan bahwa aset merupakan menjabarkan makna yang terdiri atas aset ekonomi, mental dan spritual. Hal yang serupa juga dilakukan oleh Luayyi (2012). Hasil penelitiannya menemukan makna aset terdiri atas aset lahiriyah yaitu aset ekonomi dan aset batiniyah yaitu aset mental dan spritual.

Penelitian ini dilakukan pada organisasi non profit oriented, yaitu Universitas Muhammadiyah Maluku Utara (UMMU) yang merupakan salah satu Amal Usaha Muhammadiyah (AUM) di Bidang Pendidikan Tinggi. UMMU berfungsi untuk mewujudkan cita-cita Muhammadiyah, yaitu memberantas kebodohan, kemiskinan dan sebagai sarana dakwah. Artinya, aset yang dimiliki oleh UMMU dimanfaatkan berbeda dengan konsep aset yang di gagas oleh FASB, IAI dan IASC, yaitu titik puncaknya adalah memperoleh laba, tetapi untuk kemaslahatan ummat. Oleh sebab itu, penelitian ini bertujuan untuk menemukan sisi lain dari makna aset ekonomi pada Universitas Muhammadiyah Maluku Utara yang merupakan salah satu Amal Usaha Muhammadiyah.

\section{METODE PENELITIAN}

Penelitian ini merupakan penelitian yang dilakukan dalam ranah kualitatif. Penjelesan tentang penelitian kualitatif sebagaimana dijelaskan Smith (2009:48) sebagai penelitian yang mempelajari suatu bidang antar disiplin, lintas disiplin bahkan terkadang merupakan lawan disiplin dari suatu fenomena yang terjadi. Penelitian kualitatif dapat menghubungkan ilmu pengetahuan humaniora, sosial dan sains modern yang menyebabkan penelitian ini dapat menyentuh semua sudut pandang pemikiran penulis yang ingin mengeksplorasi ide secara lebih bebas dan membumi. Menurut Sukuharsono (2006) penelitian kualitatif dapat menggunakan beberapa metode untuk menjawab penelitian. Akibatnya, secara ideal dalam melakukan riset kualitatif memerlukan komitmen yang kuat untuk mempelajari masalah, membutuhkan waktu dan biaya.

Metodologi penelitian kualitatif merupakan prosedur penelitian yang menghasilkan data diskriptif berupa kata-kata tertulis atau lisan dari orang-orang, dan perilaku yang dapat diamati, yang dipusatkan pada pengalaman individu secara utuh (Bogdan dan Taylor, 1993:5). Moleong (2006:6) juga menegaskan penelitian kualitatif adalah prosedur yang menghasilkan data-data diskriptif, yang 
meliputi kata-kata tertulis atau lisan dari orang-orang untuk memahami objek penelitian yang sedang dilakukan, tentunya harus didukung dengan studi literatur berdasarkan pendalaman kajian pustaka, baik berupa data penelitian, maupun angka yang dapat dipahami dengan baik. Sukoharsono (2006) menegaskan penelitian kualitatif merupakan teropong atas fenomena sosial (khususnya akuntansi) dengan berbagai cara pandang (teropong), warna, bentuk, macam, perilaku dan rasa, misalnya dengan aliran konstruktivis, interpretif, feminims, postmodernis, strukturalis, teori kritis, dekonstruktivis dan masih banyak yang lainnya.

Dalam penelitian ini penulis menggunakan metode interpretif fenomenologi sebagai pijakan dalam memaknai sisi lain dari aset ekonomi dalam Amal Usaha Muhammadiyah yaitu Universitas Muhammadiyah Maluku Utara. Menurut Burrell dan Morgan (1979:227) paradigma interpretif meliputi cakupan yang luas atas gagasan filosofis dan sosiologi yang memberikan karakteristik umum untuk mencoba memahami dan menjelaskan dunia sosial dengan tujuan utama untuk melihat pelaku yang secara langsung terlibat dalam proses sosial. Selain itu, paradigma interpretif menggunakan cara pandang para nominalis yang melihat realitas sosial sebagai sesuatu yang hanya merupakan label, nama, atau konsep yang digunakan untuk membangun realitas dan bukanlah sesuatu yang nyata, melainkan hanyalah penamaan atas sesuatu yang diciptakan oleh manusia atau merupakan produk manusia itu sendiri.

Audifax (2008:29) menambahkan dalam paradigma interpretif, penelitian sosial tidak selalu dan tidak secara langsung memilih nilai instrumental untuk sampai pada peramalan dan pengendalian fenomena sosial. Penelitian dilakukan untuk mengembangkan pemahaman. Penelitian membantu kita untuk mengerti dan menginterpretasi apa yang ada di balik peristiwa: latar belakang pemikiran manusia yang terlibat di dalamnya, serta bagaimana manusia meletakkan makna pada peristiwa yang terjadi. Paradigma interpretif, dalam banyak hal juga sering disebut sebagai paradigma konstruktif yang menekankan bahwa penelitian pada dasarnya dilakukan untuk memahami realitas dunia apa adanya (Denzin dan Lincoln, 2009:148).

Fenomenologi merupakan ilmu (logos) yang mempelajari tentang hal-hal yang tampak. Secara etimologi, fenomena berasal dari bahasa Yunani phainesthal berarti "yang menampakan diri". Apa yang menampakan diri? bisa macam-macam: perasaan, benda, peristiwa, pikiran, lembaga sosial dan seterusnya (Audifax, 2008:205). Fenomenologi, pada awalnya merupakan kajian filsafat dan sosiologi. Edmund Husserl sendiri, sebagai penggagas utama, menginginkan fenomenologi akan melahirkan ilmu yang lebih bisa bermanfaat bagi manusia, setelah sekian lama ilmu pengetahuan mengalami krisis dan difungsional. Fenomenologi, kemudian berkembang sebagai semacam metode riset yang diterapkan dalam berbagai ilmu sosial, termasuk akuntansi sebagai salah satu varian dalam penelitian kualitatif dengan menggunakan payung paradigma interpretif.

Menurut Muhadjir (2000:116) metode fenomenologi mengakui adanya kebenaran empiris etik yang memerlukan akal budi untuk melacak dan menjelaskan serta berargumentasi. Akal budi disini mengandung makna bahwa kita perlu menggunakan kriteria lebih tinggi lagi dari sekedar truth or false. Brouwer (1984:3) berpendapat seorang fenomenolog senang melihat gejala (fenomena). Melihat gejala merupakan dasar yang syarat mutlak untuk semua aktivitas ilmiah. Ia bukan ilmu tetapi merupakan cara pandang, metode penelitian, a way looking at things. Bagi Brouwer, fenomenologi tidak bisa hilang dan menjadi syarat mutlak bagi seseorang yang mau memikirkan dasar dari usaha ilmiah atau dasar dari hidupnya sendiri. lebih jauh, fenonomenologi mengajarkan kita untuk membiasakan diri, tidak lagi melihat benda-benda, melainkan fenomena.

Dalam penelitian fenomenologi peneliti dituntut untuk mampu mendiskripsikan fenomena yang terjadi sesuai dengan realitas di lapangan. Moustakas (1994) menjelaskan fenomenologi merupakan diskripsi pengalaman-pengalaman. 


\section{Sisi Lain \\ dari \\ Makna...}

Artinya, untuk menggambarkan seakurat mungkin sebuah fenomena, sekaligus tetap menjaga keadaan sebenarnya seperti yang nampak pada diri informan. Sementara itu, suatu fenomena yang nampak mengandung unsur sosial dan psikologis (Welman dan Kluger 1999).

Menurut Moutakas (1994) yang di kutip Kuswarno (2009:43) bahwa salah satu ciri fenomenologi yang dikembangkan Husserl adalah adanya noema dan noesis. Neoma merupakan sesuatu yang diterima oleh panca indera manusia. Menurut Husserl noema itu faithfully and in the light of perfect self-indefence. Dalam arti kata itu disertai bukti-bukti yang akurat. Sedangkan noesis merupakan bahan dasar pikiran dan roh (mind and spirit) manusia. Neosis juga menyadarkan kita akan makna, ketika mempresepsi, mengingat, menilai, merasa, dan berfikir. Neosis adalah sisi ideal obyek dalam pikiran kita, bukan obyek yang sebenarnya. Dengan noesis, suatu obyek dibawa dalam kesadaran, muncul dalam kesadaran, dan secara rasional yang ditentukan. Lebih jauh manusia berfikir, merasa, menilai dan mengingat dengan menggukan neosis. Deskripsi noesis adalah diskripsi subyektif, karena ada pemberian makna padanya.

Tahapan selanjutnya dalam fenomenologi yaitu epoche. Epoche berasal dari bahasa yunani yang berarti "menjauh dari" dan "tidak memberikan suara". Dengan epoche, peneliti di tuntut untuk menyampingkan penilaian, bias, dan pertimbangan awal yang dimilikinya terhadap suatu obyek. Artinya, epoche merupakan pemutusan hubungan dengan pengalaman dan pengetahuan yang dimiliki peneliti (Kuswarno 2009:48). Creswell (2007:59) menegaskan dengan epoche atau bracketing seorang peneliti harus menyisihkan semua bentuk prakonsep atas fenomena yang diteliti untuk memperoleh gambaran murni (fresh perspective) dari subjek penelitian. Proses ini yang disebut sebagai reduksi fenomenologis (Rapar 1996:119), satu dari tiga tahap reduksi yang ditawarkan Husserl dalam rangka membangun ilmu pengetahuan yang rigorous, yang tidak terdapat keraguan (apodiktis) di dalamnya. Reduksi tahap selanjutnya adalah reduksi eidetic. Reduksi eidetic ditujukan untuk menemukan eidos atau hakekat atau makna yang tersembunyi dari fenomena yang diamati. Pada tahap ini hakekat atau makna dimaksud sudah mulai disusun dan disajikan dalam bentuk tema-tema spesifik. Proses ini dilakukan melalui pengamatan yang seksama dan interative, bukan melalui proses yang linear (Bertens 1990). Dalam bahasa yang lain, melalui reduksi eidetic maka deskripsi tekstural (textural description) yang merupakan pengalaman informan, dan deskripsi struktural (structural description) yang menjelaskan tentang konteks penelitian dapat dihasilkan. Pada tahap akhir dilakukan reduksi transendental yang merupakan tahapan kunci dalam fenomenologi transendental Husserl. Tujuannya adalah untuk menemukan hakekat atau makna yang sesungguhnya, murni dan utuh. Prosesnya dilakukan dengan seksama, iterative, dan intuitive. Inilah puncak dari seluruh proses dalam fenomenologi transendental Husserl, yang menurut Creswell disebut sebagai "esensi" (the essence) dari hakikat atau makna pengalaman yang sesungguhnya (Creswell 2007:60).

Penelitian ini dilakukan di salah satu Amal Usaha Muhammadiyah di Indonesia bagian Timur, yaitu Universitas Muhamamdiyah Maluku Utara (UMMU). Alasan peneliti memilih lokasi ini yaitu: pertama, UMMU memiliki ciri khas yang berbeda dengan Universitas Muhammadiyah yang ada di Indonesia, di mana UMMU didirikan di tengah-tengah konflik sosial yang melanda Maluku pada tahun 1999-2000. Kedua, UMMU memiliki ciri khas atau budaya yang sarat dengan nilai-nilai religi. Ketiga, keberadaan UMMU sebagai Amal Usaha Muhammadiyah lebih mengarah pada tujuan sosial dan sarana dakwah, sehingga peneliti dapat mengetahui lebih jauh tentang konsep aset yang diterapkan di UMMU.

Informan dalam penelitian ini merupakan sumber informasi utama bagi peneliti. Peneliti akan bekerja sama dengan informan untuk menghasilkan deskripsi tentang sisi lain dari aset ekonomi. Orang-orang yang dijadikan informan yaitu mereka yang bersentuhan langsung dengan aktivitas UMMU dan memiliki pemahaman yang luas tentang organisasi Muhammadiyah, serta terlibat dalam berbagai 
Selanjutnya, melakukan pengumpulan data. Moustakas (1994) menegaskan dalam proses pengumpulan data fenomenologi, pemahaman, penilaian, dan pengetahuan sehari-hari seorang peneniliti dikesampingkan terlebih dahulu, dan fenomena direvisi secara segar, dan apa adanya. Sehingga pemahaman tersebut kemudian diikuti dengan tahapan mengingat kembali (Groenewald 2004:13). Proses menggali dan mengumpulkan data dari informan dilakukan dengan menggunakan teknik wawancara secara mendalam dan peneliti sebagai partisipan aktif, dengan cara terlibat mengikuti orang-orang yang diteliti dalam kehidupan sehari-hari, melihat apa yang mereka lakukan, kapan, dengan siapa, dalam keadaan apa, dan menanyai mereka mengenai tidakan yang dilakukan. Kehadiran peneliti sebagai partisipan aktif diharapkan memberi pemahaman lebih utuh melalui wawancara dengan menggunakan alat perekam, catatan dan teknik observasi untuk melihat secara langsung perilaku yang berhubungan dengan fenomena yang diamati (Sander 1982; Saerang dan Elia 2001:87).

Data yang telah terkumpul dibuat kompilasi tematik, data dipilah-pilah ke dalam sub-sub tema sesuai dengan tujuan penelitian. Pada tahapan ini peneliti berusaha melakukan pemahaman ke dalam alam kesadaran subyek yang berupa aktivitas-aktivitas mengingat, meresapi, dan meyakini, di mana ketiga jenis aktivitas kesadaran tersebut memiliki keterarahan pada "sesuatu" yang di dalam metodologi disebut intensionalitas (Moustakas 1994). Kalimat "sesuatu" dalam penelitian ini adalah tema penelitian itu sendiri, yaitu apa dan bagaimana subyek penelitian memberikan makna sesuai dengan posisinya dalam Amal Usaha Muhammadiyah.

\section{HASIL DAN PEMBAHASAN}

UMMU memiliki fungsi sebagai Catur Dharma yaitu: pengembangan ilmu pengetahuan, penelitian, pengabdian pada masyarakat, dan Al-Islam Kemuhammadiyaan (Statuta UMMU 2015). Catur Dharma tersebut tidak saja melekat pada UMMU, tetapi juga terhadap seluruh Amal Usaha Muhammadiyah (AUM) di Indonesia. Inilah ciri khas untuk membedakan Amal Usaha Muhammadiyah dengan Perguruan Tinggi Negeri maupun Perguruan Tinggi Swasta lainnya. Istilah Amal Usaha memiliki makna tersendiri bagi pengelola UMMU, sebagaimana diungkapkan Pak Ishak:

"Amal Usaha merupakan implimentasi dari Surah Al-Maun yang dilakukan oleh KH. Ahmad Dahlan. Makna Amal Usaha berbarti melakukan pekerjaan yang ikhlas untuk mengharapkan Amal disisi Allah SWT".

\section{Selanjutnya, diungkapkan Pak Djunaidi:}

"KH. Ahmad Dahlan terinspirasi dari surat Al-Maun, karena untuk melayani kaum dhuafa dan fakir miskin tidak hanya memberikan santunan tetapi harus lebih dari itu, maka surat Ali-Imran 104 merupakan dasar untuk mendirikan Organisasi Muhammadiyah. Selain itu, kemiskinan dan kebodohan membuat masyarakat melakukan perbuatan yang menduakan Allah SWT, seperti tahayul $^{6}$, bid'ah ${ }^{7}$, dan khurafat ${ }^{8}$. Untuk itu, Muhammadiyah harus mem-

\footnotetext{
Rektor Universitas Muhammadiyah Maluku Utara

Wakil Rektor IV Universitas Universitas Muhammadiyah Maluku Utara

Kepala Penjaminan Mutu Universitas Muhammadiyah Maluku Utara

Kepala Biro Administrasi Umum Universitas Muhammadiyah Maluku Utara

Kepala Biro Keuangan Universitas Muhammadiyah Maluku Utara

Menurut Saiful (2015:117) tahayul merupakan suatu kepercayaan yang tidak ada dasarnya

Ibid, Bid'ah merupakan perbuatan yang biasanya muncul untuk memperbanyak ibadah (ritual), tetapi pengetahuan Islamnya kurang, sehingga yang dilakukan bukan bersumber pada Islam.

8 Ibid, Khurafat merupakan kepercayaan tanpa pedoman yang sah dari Al-Qur'an dan Al-Hadist, akan tetapi hanya ikut-ikutan orang tua atau nenek moyang
} 
Sisi Lain

dari

Makna...

punyai Usaha-usaha di bidang pendidikan, kesehatan dan ekonomi. artinya bahwa dengan usaha tersebut akan mendapatkan amal disisi Allah SWT".

AUM merupakan wujud nyata gerakan dakwah amar ma'ruf nahi munkar yang dilaksanakan oelh KH. Ahmad Dahlan dan penerusnya sampai saat ini. Bahkan konsep amal usaha tersebut menjadi kunci suksesnya AUM sejak awal didirikan sampai saat sekarang dan dimasa yang akan datang.

AUM salah satunya yaitu UMMU, dimana memiliki tanggung jawab untuk mewujudkan cita-cita Muhammadiyah. Hal tersebut tertuang dalam Anggaran Dasar Muhammadiyah pasal 6 yaitu menegakkan Agama Islam, sehingga terwujudnya masyarakat Islam yang sebenar-benarnya (Pimpinan Pusat Muhammadiyah, 2010)

\section{Aset Ekonomi sebagai Sarana Dakwah}

Konflik antara Ummat Islam dan Kristen di Maluku Utara pada tahun 19992000 berdampak pada kondisi masyarakat menjadi memburuk, tidak hanya persolan agama, tetapi juga ekonomi, pendidikan, dll. Akibat kondisi yang dialami oleh masyarakat saat itu, maka Pimpinan Wilayah Muhammadiyah (PWM) Maluku Utara mendirikan UMMU pada tahun 2001 sebagai solusi untuk menjawab tantangan tersebut. Akan tetapi, UMMU juga mempunyai satu tugas yang diamanahkan oleh Muhammadiyah, untuk menyiarkan ajaran Islam sesuai Al-Qur'an dan $\mathrm{Al}$-Hadist. Oleh sebab itu, segala aset yang dimilikinya digunakan untuk mendukung hal tersebut. Sebagaimana diungkapkan Pak Ishak:

"Aset itu ya gedung, tanah, uang, dll yang bernilai ekonomi. Tapi ingat aset yang dimiliki UMMU dimanfaatkan untuk mewujudkan visi dan misi, yaitu pendidikan yang berkualitas dan memiliki karakter Keislaman. Hal itu disebabkan UMMU sebagai pilar dakwahnya Muhammadiyah”.

Lebih lanjut diungkapkan Pak Djunaidi:

"PWM Maluku Utara mendirikan UMMU sebagai solusi bagi masyarakat Maluku Utara terutama biaya pendidikan maupun kebutuhan hidup yang mau sangat mahal, karena diakaibatkan krisis ekonomi dan konflik sosial yang terjadi.Selain itu, PWM Maluku Utara mendirikan UMMU sebagai salah satu pilar Dakwah di negeri Moloku Kie Raha".

Penjelasan yang sampaikan Pak Ishak dan Pak Djunaidi bahwa aset yang dimiliki oleh UMMU yaitu aset yang bernilai ekonomi dan dimanfaatkan untuk mewujudkan dakwah Muhammadiyah di Moloku Kie Raha, karena UMMU didirikan sebagai solusi bagi masyarakat Maluku Utara akibat konflik sosial, krisis ekomomi yang berdampak terhadap mahalnya biaya hidup.

UMMU sebagai lembaga Pendidikan Tinggi juga sebagai Lembaga Dakwah Muhammadiyah di Timur Indonesia, memiliki visi dan misi untuk mewujudkan masyarakat Islam yang sebenar-benarnya berdasarkan Al-Qur'an dan Al-Hadist (Statuta UMMU 2010). Peran dakwah yang dijalankan UMMU adalah melalui aktivitas pendidikan, karena pendidikan merupakan salah satu media yang paling efektif dalam menyampaikan ilmu pengatuhuan, baik yang bersifat umum maupun khusus.

Menurut Abdurrahman (2002:82) Moloku Kie Raha memiliki dua arti kata. Pertama, Moloku diartikan sebagai satu gemgam. Kedua, Kie Raha diartikan sebagai empat gugusan gunung yang berada di Maluku Utara, yaitu Kesultanan Gapi (Ternate), Kesultanan Duko (Tidore), kesultanan Tuanane (Moti Jailolo) dan Kesultanan Besi (Makian Bacan). Jadi Moloku Kie Raha berarti empat kesultanan dalam satu genggaman 
Peran yang dilakukan oleh UMMU tidak lepas dari penggagas Muhammadiyah yaitu KH. Ahmad Dahlan. Muhammadiyah sejak awal didirikan oleh KH. Ahmad Dahlan berfokus terhadap masalah-masalah sosial terutama masalah kebodohan, kemiskinan dan penindasan, yang mengakibatkan terjadinya syirik, bid'ah dan khurafat. Hal tersebut diakibatkan tidak adanya fasilitas pendidikan, kesehatan dan agama bagi masyarakat menengah kebawa, karena pendidikan hanya bisa dinimmati oleh kaum bangsawan, sehingga KH. Ahmad Dahlan mendirikan berbagai Amal Usaha Muahammadiyah, baik surau, sekolah dan rumah sakit. Salah satu inspirasi gerakan dakwah Muhamamdiyah dari ajaran Islam yaitu Al-Qur'an ayat Ali-Imran 104:

Dan hendaklah ada di antara kamu segolongan umat yang menyeru kepada kebajikan, menyuruh kepada yang ma'ruf dan mencegah dari yang munkar, merekalah orang-orang yang beruntung. (QS, Ali-Imran: Ayat 104)

KH. Ahmad Dahlan menjadikan Ayat Ali-Imran 104 sebagai landasan mendirikan muhammadiyah, karena ayat tersebut menyuru kepada ummat Islam untuk membentuk kelompok dalam hal kebajikan dan menyeruh yang ma'rufdan mencegah dari yang munkar. Artinya, semua anggota Muhammadiyah serta amal Usaha Muhammadiyah memiliki tanggung jawab untuk mewujudkan apa yang menjadi cita-cita pendirinya, yaitu selalu berada di jalan kebajikan dan selalu menyuru kepada yang ma'ruf dan mencegah yang munkar.

\section{Aset Ekonomi sebagai Sarana Bersilaturrahim}

Selama ini pemahaman akuntan maupun masyarakat secara umum terhadap aset yang bernilai ekonomi dimanfaatkan untuk memperoleh ketenangan jiwa, yaitu: memperoleh laba, tempat tinggal, dan sebagai tempat beribadah kepada Allah SWT. Sementara tidak ada yang menempatkan aset sebagai sarana bersilaturrahim. Padahal untuk memperoleh ketenangan jiwa, yaitu laba berawal dari sillarruhaim. Bahkan beribadah kepada Allah SWT di tempat yang telah tersedia, seperti surau, musholla, dan masjid merupakan sarana untuk ummat Islam saling bersilarurahmi agar saling kenal mengenal.

Aset yang dimiliki oleh UMMU tidak hanya sekedar sebagai sarana dakwah, tetapi juga sebagai sarana bersilaturahmi. Sebagaimana diungkapkan Pak Sudarto:

"UMMU merupakan tempat pertemuan ilmiah. Segala kebijakan biasanya diputuskan di kampus, baik swasta maupun negeri. Pertemuan tersebut, menjadi ajang silaturahmi baik secara individu maupun kelompok".

Selenjutnya ditambahkan Pak Sitkun:

"UMMU sebagai Perguruan Tinggi, dimana memiliki tanggung jawab untuk melaksanakan catur dharma. Hal tersebut, dilaksanakan oleh berbagai pihak $\mathrm{BPH}$, pimpinan, dosen, pegawai, mahasiwa, pemerintah, swasta serta masyarakat yang terlibat. Artinya, ada proses silaturahmi yang terjadi baik dalam proses pendidikan dan pengajaran, penelitian, pengabdian, dan Al-Islam Kemuhammadiyahan. Selain itu, kami yang bekerja mempunyai latar belakang asal daerah, suku yang berbeda, sehingga dengan adanya UMMU kami saling mengenal antar satu dengan yang lain”.

Penjelasan yang diungkapkan Pak Sudarto dan Pak Sitkun menempatkan UMMU sebagai pelaksana catur dharma, dimana terjadinya sebuah keputusan ilmiah dilakukan. Bahkan UMMU memilki tanggung jawab untuk melaksanakan catur dharma sebagaimana tertuang dalam Statuta. Pelaksanaan Catur dharma didalamnya terdapat proses silaturahmi karena berbagai pihak terlibat baik oleh $\mathrm{BPH}$, pimpinan, dosen, pegawai, mahasiswa, pemeintah, swasta serta masyarakat. 
Sisi Lain

dari

Makna...

748
Keberadaan UMMU di Maluku Utara memberikan kemudahan kepada masyarakat Maluku Utara dan sekitarnya, baik dalam hal mengakses pendidikan juga memberikan peluang terhadap para gererasi muda untuk berkompetisi untuk menjadi BPH, pimpinan, dosen maupun pegawai. Artinya, baik mahasiswa maupun pengelola UMMU berasal dari latar belakang budaya, suku, etnis yang berbedabeda. Oleh sesab itu, keberadaan UMMU tidak hanya sebagai Lembaga Pendidikan Tinggi dan sarana dakwah Muhammadiyah, tetapi juga sebagai sarana bersilaturrahim.

Keistiweaan dari salah satu silaturahmi adalah mempermudah riziki. Sillaturrahim menjadi seruan bagi umat Islam, karena dapat menimbulkan berbagai macam hal, mulai dari hubungan emosional, kasih sayang, dan persatuan. Nabi Muhammad SAW bersabda "barangsiapa ingin dilapangkan rezikinya dan diperpanjang umurnya, hendaklah ia bersilaturrahim (HR. Bukhari dan Muslim)". Oleh sebab itu, silaturrahim yang terjadi natar pengelola UMMU merupakan salah satu sumber untuk memperoleh pendapatan, baik pendapatan secara materi, sosial, dan spiritual.

\section{Aset Ekonomi sebagai Sarana Keberlanjutan Organisasi}

Aset dapat dikatakan aset ketika dapat memberikan manfaat di masa yang akan datang, jika aset tidak dapat memenuhi hal tersebut maka tidak digolongkan sebagai aset. Hal tersebut, sah-sah saja karena terdapat biaya yang dikeluarkan di masa lalu untuk memperoleh aset. Bahkan manfaat aset tidak hanya kepada pemilik perusahaan, tetapi juga para karyawan. Aset yang dipahami oleh pengelola UMMU tidak jauh berbeda dengan apa yang selama ini dipahami oleh masyarakat secara umum, tetapi memiliki sisi yang berbeda. Sebagaimana di ungkapkan Ishak:

"Aset UMMU saat ini merupakan investasi dimasa lalu, baik dari segi SDM, sarana dan prasarana. Hal tersebut dimanfaatkan untuk kepentingan UMMU dimasa yang akan datang. Artinya, semua kekayaan UMMU dignakan dan dimanfaatkan untuk mewujudkan apa yang cita-cita UMMU dan Muhammadiyah dimasa yang akan datang".

Lebih lanjut diungkapkan pak Agus:

"Aset atau kekayaan yang dimiliki oleh UMMU baik berupa SDM, sarana dan prasarana digunakan untuk mewujudkan visi dan misi baik dimasa lalau, sekarang dan dimasa yang akan datang. Aset UMMU memberikan konstribusi yang sangat signifikan, karena UMMU memiliki 16 program studi S1 dan S2 pasca sarjana yang telah mendapat nilai akreditas untuk S1 yaitu 14 nilainya B dan $3 \mathrm{C}$, sedangkan untuk pasca sarjana yaitu B. Artinya, tanpa asset tidak mungkin UMMU dapat mendapatkan nilai tersebut".

Dari penjelasan Pak Ishak dan Pak Agus bahwa aset sebagai sarana keberlanjutan UMMU, baik SDM, sarana dan prasana dimanfaatkan untuk kepentingan UMMU dan Muhammadiyah di masa yang akan datang. Asset yang dimiliki UMMU memberikan konstribusi signifikan, dimana UMMU mampu memperoleh kepercayaan baik dari pemerintah, swasta bahkan masyarakat yaitu UMMU memiliki 17 program studi dan 1 pasca sarjana dengan nilai yang telah diharapkan.

Aset yang bernilai ekonomi seperti sarana dan prasarana yaitu: gedung, tanah, bangunan, uang, dimanfaatkan untuk masa depan UMMU. Artinya, aset yang bernilai ekonomi memiliki peran penting dalam keberlanjutan UMMU, karena tanpa hal tersebut UMMU tidak bisa bertahan dalam pengelolaan organiasasi. Keberadaan aset ekonomi juga memberikan dampak yang sangat posiif terhadap UMMU, karena masyarakat dapat menyaksikan secara langsung perkembangan UMMU dan menyakini akan membawa perubahan bagi masyarakat Maluku Utara. Oleh sebab itu, Konstribusi aset bernilai ekonomi yang dimiliki UMMU, sesuai Financial Accounting Standar Board (FASB) sebagaimana diterjemahkan 
Suwarjono (2006:252) suatu aset dapat dikatakan aset ketika dapat memberikan konstribusi di masa yang akan datang. Konstribusi yang diberikan aset tidak hanya sakadar ekonomi tetapi juga sosial dan spritual.

\section{SIMPULAN}

UMMU sebagai Amal Usaha Muhammadiyah yang bergerak di bidang Pendidikan Tinggi, memiliki tanggung jawab tidak hanya sebagai sarana pemberantasan kebodohan, tetapi juga sebagai sarana dakwah, sehingga tidak terjadi perbuatanperbuatan syirik, bid'ah dan khurafat. Artinya, aset yang dimiliki oleh UMMU harus dikelola untuk mewujudkan hal tersebut, baik yang bersifat ekonomi, maupun non ekonomi.

Hasil penelitian menunjukan bahwa pengelola UMMU memaknai aset terbagi penjadi beberapa makna, antara lain: pertama, aset dimaknai sebagai sarana dakwah, yaitu akibat krisis ekonomi dan dampak dari konflik sosial yang terjadi di Maluku Utara yang mengakibatkan mahalnya biaya hidup dan biaya pendidikan, dengan keberadaan UMMU menjadi solusi bagi masyarakat Maluku Utara. Kedua, aset dimaknai sebagai sarana bersilaturahmi, hal ini berkaitan pelaksanaan catur dharma yaitu pendidikan pengajaran, penelitian, pengabdian dan Al-Islam Kemuhammadiyahan. Hal tersebut melibatkan berbagai pihak yaitu, BPH, pimpinan, dosen, mahasiswa, pemerintah, swasta dan masyarakat, dengan demikian terjadilah proses silaturahmi antar berbagai pihak-pihak ersebut. Ketiga, aset dimaknai sebagai sarana keberlanjutan, yaitu berkaitan dengan aset yang dimanfaatkan untuk mewujudkan cita-cita UMMU dan muhammadiyah dimasa yang datang.

Berdasarkan hasil penelitian, jika dikaitkan dengan konsep aset yang digagas oleh Financial Accounting Standar Board (FASB) sebagaimana diterjemahkan Suwarjono (2006:252) sebagai manfaat ekonomi masa mendatang yang cukup pasti yang diperoleh atau dikuasai/dikendalikan oleh suatu entitas sebagai akibat transaksi atau kejadian di masa lalu. Tentunya, konsep aset yang di gagas FASB masih sangat sempit karena aset hanya diakui sebagai aset, jika akan memberikan manfaat ekonomi. Sementara para pengelola UMMU memaknai aset tidak hanya aspek ekonomi tetapi juga aspek spiritual dan sosial, yaitu sebagai sarana dakwah dan sarana bersilaturrahim. Pada akhirnya, dapat disimpulkan bahwa aset merupakan sarana dakwah, sarana sillaturrahim dan sarana keberlajutan untuk mewujudkan masyarakat Islam yang sebenar-benarnya, berdasarkan Al-Qur'an dan Al-Hadist.

\section{DAFTAR PUSTAKA}

. 2002. Al-Qur'an dan Terjemahnya. Al-Mizan Publishing House: Bandung.

Audifax. 2008. Research. Sebuah Pengantar untuk "Mencari Ulang" Metodologi Penelitian dalam Psikologi. Jalasutra: Yogyakarta dan Bandung

Abdurrahman, Y.M. 2002. Kesultanan Ternate Dalam "Jou Ngon Ka Dada Madopo, Fangare Ngom Ka Alam Madiki”. Media Pustaka: Manado

Bertens, K. 1987. Fenomenologi Eksistensial. Jakarta: Gramedia

Berger, P.L., dan T. Luckman. 1990. Social Contruction Theory, Hasan Basari (Penerjemah). Tafsir Sosial atas Kenyataan: Risalah tentang Sosiologi Pengetahuan. LP3ES: Jakarta

Bogdan, R dan S. Taylor. 1993. Doing Field Research: Pratice and Meta-theory in Conterpoint, Jurnal of Management and Accounting Research 
Sisi Lain

dari

Makna...

750
Denzin, N.K. dan Y.S. Lincoln. 2009. Handbook of Qualitative Research. California-USA: Sage Publication.

Creswell, J. W. 2007. Qualitatif Inquiry and Research Design. Sage Publication, Inc

Flomhotz. E. 1974. Human Resorce Accounting, Valuation and Duration of Futball Player Contracts. Jurnal Of Managent Studies.

Groenewald, T. 2004. A Phenomenological Research Design Illustrated. International Journal of Qualitative Methods, 3 (1)

Harahap, S.S. 2011. Teori Akuntansi. Raja Grafindo Persada: Jakarta

Ikatan Akuntansi Indonesia. 2009. Standar Akuntansi Keuangan. Salemba Empat: Jakarta

Kuswarno, E. 2009. Metodologi Penelitian Komunikasi Fenomenologi. Bandung: Widya Padjajaran

Luayyi. 2012. Makna Aset dan Pelaporan Pondok Pasantren. MSA Tesis, Universitas Brawijaya

Muhajir, N. 2000. Metodologi Penelitian Kualitatif. Penerbit Rake Sarakin: Yogjakarta

Moleong, L.J. 2006. Metode Penelitian Kualitatif. Bandung: ROSDA

Moustakas, C. 1994. Phenomelogical Reseaech Methods. New Delhi: Sage Publications

Pimpinan Pusat Muhammadiyah, 2010. Anggaran Dasar dan Anggaran Rumah Tangga Muhammadiyah. Surya Sarana Grafika: Yogyakarta

Saifullah. 2015. Pergeseran Politik Muhammadiyah. Pustaka Pelajar:Yogyakarta

Suwarjono. 2006. Teori Akuntansi Perakayasaan Laporan Keuangan. BPFE: Yogyakarta

Sukuharsono, E.G. 2006. Alternatif Riset Kualitatif Sains Akuntansi: Biografi, Phenomenologi, Grounded Teory, Etrnografis Kritis, dan Studi Kasus. Analisis Makro dan Mikro: Jembatan Kebijakan Ekonomi Indonesia. 6 (2), 230-245

Smith, J.A., P. Flowers, and Larkin. Michael. 2009. Interpretative phenomenological analysis: Theory, method and research. Los Angeles, London, New Delhi, Singapore, Washington: Sage

Smith, J.A. (Ed.). 2009. Psikologi kualitatif: Panduan praktis metode riset. Terjemahan dari Qualitative Psychology A Practical Guide to Research Method. Yogyakarta: Pustaka Pelajar

Statuta Universitas Muhammadiyah Maluku Utara. 2003. UMMU Press: Ternate

Welman, C.J., dan S. J. Kluger 1999. Research Methodology for the Business and Administration Science. International Thomson: Johannesburg 
